Filozofska fakulteta, Univerza v Ljubljani

mojca.leskovec@ff.uni-lj.si

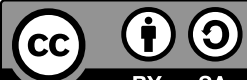

\title{
WEITBLICK: DAS GROßE PANORAMA: KURS- UND ÜBUNGSBUCH B1+
}

Anielski, Maren/ Falch, Bernhard/Finster, Andrea/Magersuppe, Jens/Würz, Ulrike/ Herzberger, Julia/Stander, Julia (2019). Weitblick: Das große Panorama: Deutsch als Fremdsprache: Kurs- und Übungsbuch B1+. Berlin: Cornelsen Verlag. ISBN: 978-3-06120883-7, mehka vezava, 200 strani, 19,99€.

UVOD

Učno gradivo za nemščino kot tuji jezik Weitblick $B 1+$ poleg pregledanega učbenika in delovnega zvezka obsega še aplikacije za učenje, avdioposnetke za prenos in kot zgoščenko ter digitalni in tiskani učiteljski priročnik. Dodatno gradivo ponujata tudi spletna stran http://www.cornelsen.de/codes in platforma Scook https://www.scook.de/, kjer je prav tako na voljo učbenik v e-obliki.

\section{2}

\section{ZASNOVA UČBENIKA}

Učbenik se prične z dvojno stranjo, namenjeno uvajanju v učno gradivo ter učenje z njim in s skupino. Sestavlja ga osem enot, vsakokrat z desetimi stranmi, od tega šestimi stranmi vnosa besednih zvez in jezikovnih struktur prek besedil ter tremi stranmi modularnega dela, čemur sledi zaključna stran s povzetkom pomembnih besednih zvez enote. Medtem ko v rednem delu uporabniki in uporabnice uravnoteženo razvijajo vseh pet spretnosti, vključno s slušno-vidnim razumevanjem, pa tudi slovnico in besedišče ter učne strategije, je modularni del namenjen krepitvi spretnosti ter ponovitvi in poglobitvi besedišča in jezikovnih struktur, učitelju oz. učiteljici pa omogoča neposredno izvajanje notranje diferenciacije. Na zadnjih straneh učbenika najdemo obsežen pregled slovnice, partnersko stran z dopolnjenimi podatki za delo v dvojicah ter seznama nepravilnih glagolov in glagolov s predlogi. 
Učno gradivo Weitblick $B 1+$ z nadaljnjim razvijanjem splošnih zmožnosti in specifičnih sporazumevalnih zmožnosti uresničuje temeljni cilj pouka nemščine kot tujega jezika, kot ga opredeljuje aktualni učni načrt za pouk nemščine v gimnaziji (UN 2008), tj. razvijanje medkulturne in medjezikovne zmožnosti. Dijaki in dijakinje ju razvijajo v okviru enot, naslovljenih Preprosto preizkusiti, Nekaj povedati, Nasmejati se iz srca, Vzeti si čas, Neizmerno se jeziti, Skupaj se spominjati, Najti rešitev in Izpolniti želje, ki se nanašajo na teme Medčloveški odnosi, Prosti čas in zabava, Potovanje in promet, Kultura, umetnost, medkulturnost, Znanost, tehnologija, množični mediji, Delo in poklic, storitvene dejavnosti, Družina in stanovanje, Narava in varstvo okolja ter Telo in zdravje, priporočene v UN-ju (2008). Pri tem je vsaka tema predstavljena z različnih vidikov; prva navedena tema Preprosto preizkusiti recimo vključuje podteme Spoznati nove ljudi, Oditi za leto dni, Drugače odkrivati mesta, Digitalni sosedje, Rudirockt in Viskanju zaklada. Gradivo tako poglablja obsežen nabor tem, okvirno obravnavanih na predhodnih ravneh učenja, in hkrati nagovarja raznolike interese uporabnikov in uporabnic.

Poleg zmožnosti sporazumevanja v tujem jeziku z gradivom Weitblick $B 1+$ dijaki in dijakinje razvijajo tudi preostale ključne kompetence za vseživljenjsko učenje, še posebej digitalno pismenost in učenje učenja. Gradivo jim poleg že običajnega e-učbenika in spletnih interaktivnih vaj namreč ponuja široko digitalno podporo prek brezplačno dostopnih aplikacij z avdio- in videoposnetki k enotam ter dodatnimi nalogami različnih ravni zahtevnosti in navedbami spletnih povezav za nadaljnje raziskovanje - vse to po motu prinesi svojo napravo (BYOD) preprosto dostopno s pametnim telefonom ali tablico. Sposobnost učinkovitega obvladovanja lastnega učenja krepijo jasna zgradba gradiva, sprotna navedba učnih ciljev v učbeniških enotah, preglednica najpomembnejših besednih zvez enote na njeni vsakokratni zadnji strani in predvsem eksplicitno urjenje učnih strategij. Kulturno zavest in izražanje ter v okviru tega literarne zmožnosti pa neposredno razvijata dve učbeniški enoti.

$\mathrm{Z}$ gradivom Weitblick $B 1+$ dijaki in dijakinje $\mathrm{v}$ nemščini kot ciljnem jeziku uravnoteženo dalje razvijajo ne le receptivne in produktivne zmožnosti, temveč skladno $\mathrm{z}$ novimi dopolnitvami dokumenta SEJO (2018) poudarjeno tudi interakcijo in mediacijo ter medkulturno in raznojezično zmožnost. Slovnično zmožnost kot ključni sestavni del sporazumevalne zmožnosti dijaki in dijakinje razvijajo s samostojnim odkrivanjem jezikovnih zakonitosti, kar dopolnjujejo nazorni prikazi v enotah in napotitve $\mathrm{v}$ slovnične preglednice na koncu učbenika. Ponavljanje besedišča ciljnega jezika in usvajanje novih besednih zvez poteka $\mathrm{v}$ okviru besedil, z raznoliko vizualno podporo in s pomočjo namigov o učinkovitih učnih strategijah. Gradivo Weitblick $B 1+$ se s posredovanimi strategijami za slušno razumevanje in pisno izražanje $\mathrm{v}$ stalni sporočanjski obliki ter vajami za posamezne dele izpita izkaže tudi kot primeren pripomoček za pripravo na splošni maturitetni izpit iz nemščine na osnovni ravni. 


\section{$4 \quad$ METODIČNO-DIDAKTIČNI PRISTOP}

Pristop učnega gradiva Weitblick $B 1+$ povzemajo naslednja didaktično-metodična načela: medkulturnost in raznojezičnost ter usmerjenost $\mathrm{k}$ opravilom in uporabniku/uporabnici. Učno gradivo na tej ravni zares odpre pot pluralnim pristopom, ki jih v okviru druge enote tudi tematizira; vključevanje drugih jezikov v proces učenja tako vendarle ne ostaja več le v domeni učitelja oz. učiteljice. Weitblick B1+ dijake in dijakinje nadalje pripravlja in navaja na uporabo jezika v avtentičnih situacijah. Pri tem nagovarja različne učne tipe in upošteva raznolikost učnih slogov, učitelju/učiteljici pa tako v rednem kot v modularnem delu enot omogoča notranjo diferenciacijo pri vsebini in nalogah ter s tem upoštevanje različnega predznanja in siceršnjih individualnih posebnosti dijakov in dijakinj. Z izborom aktualnih tem, kot so aplikacije, hitri zmenki, plogging, roboti, trendi, gradivo pritegne zanimanje mlajših odraslih in ohranja njihovo motivacijo za učenje.

\section{$5 \quad$ ZAKLJUČEK}

Ocenjujem, da gradivo Weitblick $B 1+$ učinkovito krepi in nadgrajuje raven sporazumevalnega praga uporabnikov in uporabnic, skladno s SEJO-m predvsem z večanjem količine posredovanih stvarnih informacij. Ti tako po predelanem učnem gradivu tvorijo ne le preprosta besedila ter kratko utemeljujejo in pojasnjujejo v nemščini kot ciljnem jeziku, temveč tudi omejeno natančno opisujejo, podajajo podrobnosti in napotke ter samozavestneje sodelujejo v izmenjevanju nakopičenih informacij. Učno gradivo je pri tem usklajeno z najnovejšimi spoznanji o učenju in poučevanju tujega jezika ter že upošteva tudi dopolnitve k dokumentu SEJO (2018). 